\title{
High pressure phase equilibrium constraints on the origin of eclogites
}

\author{
Presnall, D. C. ${ }^{1}$ and Walter, M. J. ${ }^{2}$
}

1. Magmalogy Laboratory, Department of Geosciences, University of Texas at Dallas, P.O. Box 830688, Richardson, TX, 75083-0688, USA

2. Institute for Study of the Earth's Interior, Okayama University, Misasa, Tottori-ken 682-01, Japan

Eclogites have been considered to represent subducted oceanic crust (MacGregor and Manton, 1986; Beard et al., 1996), residues from the production of Archean crust (Ireland et al., 1994; Rollinson, 1997), and cumulates from high pressure mantle magmas (O'Hara and Yoder, 1967; MacGregor and Carter, 1970; Smyth et al., 1989; Taylor and Neal, 1989). We do not attempt to examine all these possible origins. Instead, we concentrate on the possibility of a high pressure cumulate origin for eclogite xenoliths found in kimberlite pipes.

In the $\mathrm{CaO}-\mathrm{MgO}-\mathrm{Al}_{2} \mathrm{O}_{3}-\mathrm{SiO}_{2}$ (CMAS) system, Milholland and Presnall (1998) determined liquidus phase relations for the model tholeiitic basalt tetrahedron, forsterite-diopside-anorthite-quartz at 3.0 $\mathrm{GPa}$. They found a large divariant liquidus surface along which garnet and clinopyroxene (model bimineralic eclogite) crystallize. This surface expands with pressure at least up to $5 \mathrm{GPa}$ (Weng and Presnall, 1995). It is bounded at $3.0 \mathrm{GPa}$ by six liquidus boundary lines along which one of the six additional phases, spinel, sapphirine, corundum, kyanite, quartz, and orthopyroxene is present in addition to garnet and clinopyroxene. Each of these univariant boundary lines terminates at either end against an isobaric invariant point except that in one case, the termination occurs at an invariant point in $\mathrm{P}-\mathrm{T}$ space. The set of isobaric invariant points correspond to the assemblages, $\mathrm{gt}+\mathrm{cpx}+\mathrm{sp}+\mathrm{sa}$ + liq, gt $+\mathrm{cpx}+\mathrm{sa}+\mathrm{cor}+\mathrm{liq}, \mathrm{gt}+\mathrm{cpx}+\mathrm{cor}+\mathrm{ky}+\mathrm{liq}, \mathrm{gt}+\mathrm{cpx}+\mathrm{ky}+\mathrm{qz}+\mathrm{liq}$, and $\mathrm{gt}+\mathrm{cpx}+\mathrm{qz}$ + en + liq. The invariant point in P-T space has the assemblage ol + opx $+\mathrm{cpx}+\mathrm{gt}+\mathrm{sp}+\mathrm{liq}(\mathrm{gt}$, garnet; cpx, clinopyroxene; opx, orthopyroxene; sp, spinel; sa, sapphirine; cor, corundum; ky, kyanite; qz, quartz; fo, forsterite; liq, liquid). Liquids on the gt/cpx surface that crystallize bimineralic eclogite range from model picritic basalt to an intermediate composition. Liquidus temperatures on this surface range from $1568^{\circ} \mathrm{C}$ for the most magnesian liquids to $1400^{\circ} \mathrm{C}$ for the most siliceous.

We have determined by microprobe the compositions of coexisting garnet, clinopyroxene and liquid for a wide range of points on the divariant gt/cpx surface. The run products were kindly supplied by C. S. Milholland and the run conditions are reported in Milholland and Presnall (1998). From these data we have fitted a surface to the liquid composition data. For each determined liquid composition on the surface and the known compositions of the coexisting garnet and clinopyroxene, we have calculated the bulk composition of the crystallizing assemblage, the relative proportions of garnet and clinopyroxene in this assemblage, and the tangent to the liquidus fractionation line passing through the liquid. From these tangents, we have constructed liquidus fractionation lines, which define the liquid path for fractional crystallization of any composition on the surface.

Our data and that of Milholland and Presnall (1998) show that during fractional crystallization at 3.0 $\mathrm{GPa}$, the liquid that crystallizes bimineralic eclogite changes from an initial model picrite (47.3\% $\left.\mathrm{SiO}_{2}, 17.0 \% \mathrm{Al}_{2} \mathrm{O}_{3}, 22.1 \% \mathrm{MgO}, 13.5 \% \mathrm{CaO}\right)$ to an intermediate composition $\left(56.8 \% \mathrm{SiO}_{2}, 2.2 .1 \%\right.$ $\mathrm{Al}_{2} \mathrm{O}_{3}, 6.3 \% \mathrm{MgO}, 14.8 \% \mathrm{CaO}$ ). During this fractional crystallization, cumulus clinopyroxene increases in $\mathrm{CaO}$ (from 13.7 to $20.8 \%$ ) and $\mathrm{Al}_{2} \mathrm{O}_{3}$ (from 9.0 to $18.9 \%$ ), and decreases in $\mathrm{MgO}$ (from 25.1 to $12.8 \%$ ). The corresponding change in composition of the cumulus garnet is from $\mathrm{Py}_{86} \mathrm{Gr}_{14}$ to $\mathrm{Py}_{79} \mathrm{Gr}_{21}$ (mole). Phases in addition to garnet and clinopyroxene in equilibrium with the most magnesian liquid are olivine and orthopyroxene. The most siliceous liquid is in equilibrium with the additional phases kyanite and quartz; and other liquids, only slightly less siliceous are in equilibrium with corundum The most magnesian liquid lies very close to the aluminous pyroxene plane. Thus, if interstitial melt were trapped in the garnet-clinopyroxene cumulus assemblage, the only result would be crystallization of additional garnet and clinopyroxene. On cooling and crystallization, the liquid would move away from the aluminous pyroxene plane toward more aluminous and siliceous intermediate compositions, and the possibility of forming interstitial corundum, kyanite, or quartz 
from trapped melt would increase. Alternatively, these minerals could also form as cumulus phases crstallized from certain of the more fractionated liquids.

On the basis of the MgO content of garnet, Hills and Haggerty (1989) and Fung and Haggerty (1995) divided 41 selected eclogite samples from the Koidu kimberlite complex, Sierra Leone, into high$\mathrm{MgO}$ and low-MgO types. High-MgO eclogites have diopsidic clinopyroxene with $\mathrm{Al}_{2} \mathrm{O}_{3}<4.1 \%$ and garnets with $\mathrm{Gr} /(\mathrm{Gr}+\mathrm{Py})<25$. Low-MgO eclogites have omphacitic and aluminous (up to $17.6 \%$ $\left.\mathrm{Al}_{2} \mathrm{O}_{3}\right)$ clinopyroxene and garnet with $\mathrm{Gr} /(\mathrm{Gr}+\mathrm{Py})>25$. Also, corundum, kyanite, and quartz occur in the low-MgO eclogites from the Koidu kimberlite but are absent from the high-MgO eclogites. Similar compositional and accessory mineral relationships exist for eclogites from the Udachnaya mine in Russia (Snyder et al., 1997) and from southern Africa (MacGregor and Carter, 1970; Shervais et al., 1988; Taylor and Neal, 1989; Smyth et al., 1989).

The correspondence between the mineralogical and chemical changes expected from the phase relations and those found in natural eclogites is striking and suggests that consideration should be given to a high pressure cumulate origin for the complete compositional range of eclogites found in kimberlites. According to this scenario, high-MgO eclogites would be cumulates from picritic magmas and these would grade continuously into low-MgO eclogites formed as cumulates from magmas of intermediate composition enriched in $\mathrm{SiO}_{2}$ and $\mathrm{Al}_{2} \mathrm{O}_{3}$ and depleted in $\mathrm{MgO}$. The phase relations also suggest that a cumulus and/or intercumulus origin for corundum, kyanite, and quartz in the low-MgO eclogites should be considered.

Oxygen isotope data, which suggest that many eclogites, particularly the low-MgO types, are derived from ancient subducted crust (MacGregor and Manton, 1986; Beard et al., 1996), present a potentially severe problem for generalized application of a high pressure cumulate model. However, it is unsatisfying to suggest that certain eclogite xenoliths with oxygen isotope ratios that deviate from the mantle value must be plucked out of an otherwise coherent picture and assigned a completely different origin. An issue that appears not to have have been adequately addressed so far is the possibility of modification of the intrinsic oxygen isotopic composition of eclogite xenoliths during their entrainment in the erupting kimberlite. In this regard, the extensive alteration of Yakutian eclogite xenoliths figured and discussed by Snyder et al. (1997) should be noted.

Ancient cratons have been generally found to overly a mantle root that is correspondingly ancient. This suggests that the mantle roots have always remained attached. We propose that eclogites from such cratonic areas may be cumulates remaining from fractional crystallization of a Hadean magma ocean that produced the continental proto-crust as a residual liquid. In this regard, an important aspect of our data is that the final residual liquid produced by fractional crystallization at $3 \mathrm{GPa}$ has an intermediate composition with similarities to the average composition of the continental crust.

\section{References}

Beard, B. L., Fraracci, K. N., Taylor, L. A., Snyder, G. A., Clayton, R. A., Mayeda, T. K., Sobolev, N. V., 1996, Petrography and geochemistry of eclogites from the Mir kimberlite, Yakutia, Russia: Contrib. Mineral. Petrol.: v. 125, p. 293-310.

Fung, A. T., and Haggerty, S. E., 1995, Petrography and mineral compositions of eclogites from the Koidu Kimberlite Complex, Sierra Leone, Jour. Geophys. Res., v. 100, p. 20,451-20,473.

Hills, D. V., and Haggerty, S. E., 1989, Petrochemistry of eclogites from the Koidu Kimberlite Complex, Sierra Leone: Contrib. Mineral. Petrol. v. 103, p. 397-422.

Ireland, T. R., Rudnick, R. L., Spetsius, Z., 1994, Trace elements in diamond inclusions from eclogites reveal link to Archean granites: Earth Planet. Sci. Lett., v. 128, p. 199-213.

MacGregor, I. D., and Carter, J. L., 1970, The chemistry of clinopyroxenes and garnets of eclogite and peridotite xenoliths from the Roberts Victor mine, South Africa: Phys. Earth Planet. Inter., v. 3, p. 391-397.

MacGregor, I. D., and Manton, W. I., 1986, Roberts Victor eclogites: Ancient oceanic crust: Jour. Geophys. Res. v. 91, p. 14,063-14,079.

Milholland, C. S., and Presnall, D. C., 1998, Liquidus phase relations in the $\mathrm{CaO}-\mathrm{MgO}-\mathrm{Al}_{2} \mathrm{O}_{3}-\mathrm{SiO}_{2}$ system at $3.0 \mathrm{GPa}$ : The aluminous pyroxene thermal divide and high pressure fractionation of picritic and komatiitic magmas: Jour. Petrol., in press, January issue. 
O'Hara, M. J., and Yoder, H. S., Jr., 1967, Formation and fractionation of basaltic magmas at high pressure, Scott. Jour. Geol, v. 3, p. 67-117.

Rollinson, H., 1997, Eclogite xenoliths in west African kimberlites as residues from Archaean granitoid crust formation: Nature, v. 389, p. 173-176.

Shervais, J. W., Taylor, L. A., Lugmair, G. W., Clayton, R. N., Mayeda, T. K., and Korotev, R. L., 1988, Early Proterozoic oceanic crust and the evolution of subcontinental mantle: Eclogites and related rocks from southern Africa: Geol. Soc. Am. Bull., v. 100, p. 411-423.

Smyth, J. R., Caporuscio, F. A.and McCormick, T. C., 1989, Mantle eclogites: evidence of igneous fractionation in the mantle: Earth Planet. Sci. Lett., v. 93, p. 133-141.

Snyder, G. A., Taylor, L. A., Crozaz, G. Halliday, A. N., Beard, B. L., Sobolev, V. N., and Sobolev, N. V., 1997, The origins of Yakutian eclogite xenoliths: Jour. Petrol., v. 38, p. 85-113.

Taylor, L. A., and Neal, C. R., 1989, Eclogites with oceanic crustal and mantle signatures from the Bellsbank kimberlite, Soutn Africa, Part I: Mineralogy, petrography, and whole rock chemistry: Jour. Geology, v. 97, p. 551-567.

Weng, Y.-H., and Presnall, D. C., 1995, Constraints on the depth of origin of komatiites based on melting relations in the system $\mathrm{CaO}-\mathrm{MgO}-\mathrm{Al}_{2} \mathrm{O}_{3}-\mathrm{SiO}_{2}$ at $5 \mathrm{GPa}$ : EOS Trans. Am. Geophys. Union, v. 77. p. F696-F697. 